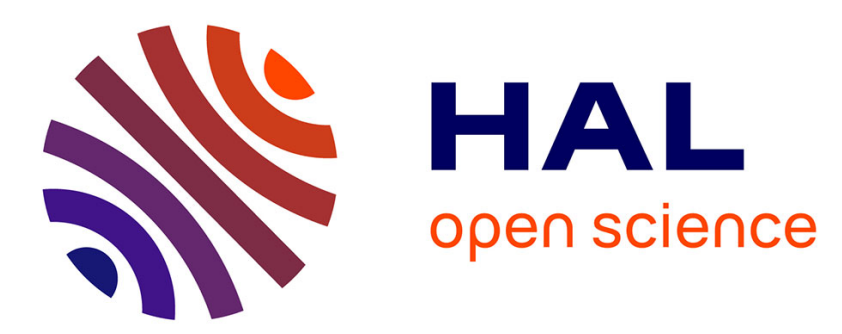

\title{
Caring for Victims of Human Trafficking: Staging and Bridging Cultural Differences in Germany and France
}

\author{
Mathilde Darley, Anne Dölemeyer
}

\section{To cite this version:}

Mathilde Darley, Anne Dölemeyer. Caring for Victims of Human Trafficking: Staging and Bridging Cultural Differences in Germany and France. Sociologus. Zeitschrift für empirische Ethnosoziologie und Ethnopsychologie/Journal for Empirical Social Anthropology, 2020. halshs-03084409

\section{HAL Id: halshs-03084409 \\ https://shs.hal.science/halshs-03084409}

Submitted on 21 Jul 2021

HAL is a multi-disciplinary open access archive for the deposit and dissemination of scientific research documents, whether they are published or not. The documents may come from teaching and research institutions in France or abroad, or from public or private research centers.
L'archive ouverte pluridisciplinaire HAL, est destinée au dépôt et à la diffusion de documents scientifiques de niveau recherche, publiés ou non, émanant des établissements d'enseignement et de recherche français ou étrangers, des laboratoires publics ou privés. 


\title{
Caring for Victims of Human Trafficking: Staging and Bridging Cultural Differences in Germany and France
}

\section{Fachberatungsarbeit bei Opfern von Menschenhandel als Inszenierung und Überbrückung kultureller Differenz}

\author{
Mathilde Darley* \\ Anne Dölemeyer**
}

\begin{abstract}
According to prosecuting authorities, victims trafficked into sexual exploitation are difficult to identify; it seems even harder to find 'appropriate' victims willing to testify in court. This is often ascribed to 'cultural differences' rooted in their (supposedly) foreign origin.

In our contribution, we show how counselling centres for trafficking victims in France and Germany help to identify victims and to make them more suitable for prosecuting authorities. In doing so, we argue that these counselling centres position themselves as indispensable 'cultural translators': they help public authorities understand the victims, and they help the victims understand public authorities, thus providing the basis for any criminal procedure. Despite very different structures and legal circumstances between France and Germany, we found a number of similarities in how staff at German and French counselling centres first establish such cultural differences as a given to then be able to bridge them. In doing so, we argue, they (even unintendedly) contribute to ethnicising and further othering their clients, especially highly marginalized 'groups' like 'Nigerians' and 'Roma'.
\end{abstract}

Keywords: state ethnography; NGOs; human trafficking; construction of cultural differences Schlagwörter: Staatsethnographie; NRO; Menschenhandel; Konstruktion kultureller Differenz

\section{Introduction}

How are marginalized foreign subjects made governable in Western European nations, and what role does the topos of cultural differences and overcoming these differences play therein? In this paper, we take up this question from a comparative perspective using the example of persons identified as victims of human trafficking into prostitution in the French and German contexts and focusing on the work of counselling centres for trafficking victims. ${ }^{1}$ Both countries face high estimates of trafficking victims on the one hand, relatively few identified cases on the other. As a result of merging the abolitionist and feminist positions on prostitution and trafficking during the 1990s (Mathieu 2014), human trafficking has been quite high on the international and European political agenda

\footnotetext{
* CNRS Researcher, CESDIP, 43 Boulevard Vauban, 78280 Guyancourt, France, Email: mathilde.darley@cesdip.fr

${ }^{* *}$ Researcher, University of Applied Sciences HAWK, Hildesheim. HAWK, Fakultät M, Haarmannplatz 3, 37603 Holzminden, Email: anne.doelemeyer@hawk.de

${ }^{1}$ This article presents results from the French-German project "Proscrim: Institutionalizing Trafficking", which examines institutional practices of identifying and accessing victims of trafficking for the purpose of sexual exploitation from an ethnographic perspective. The project was supported by the DFG in Germany and by ANR (ANR-13-FRAL-0014) in France.
} 
in the last decades (Darley 2006, Ragaru 2007). Although producing numbers on it is per se challenging and the available estimations and their instrumental use for political and ideological purposes are highly contested (Mathieu 2012), trafficking in human beings is considered one of the most lucrative areas of international organized crime (UNO 2000). However, the number of criminal proceedings and victims identified by the police remain relatively low. To explain this paradox, enforcement agencies and activists usually underline that the actual number of cases is believed to be far higher (e.g. BKA 2017, UNODC 2018), but that identifying victims requires them to fulfil a high number of prerequisites.

Despite highly differing legal frameworks and structures in France and Germany, counselling centres play a central role in both countries in identifying victims and making them visible, understandable and governable within the logics of the state and the criminal justice system. They do so by performing certain kinds of translation work: more specifically, they construct and emphasize cultural differences, partly to then define their work as bridging these differences. This occurs both in France and Germany, taking on different forms but leading to very similar effects: In both countries, we argue, the concept of 'cultural differences' is used as a tool not only to better understand the populations labelled as different, but also to govern these otherwise illegible populations.

Various studies have shown that the features of victims of trafficking on the one hand and the requirements placed on them by the particular logics of criminal, social law or of administrative techniques on the other hand do not match up (Jaksic 2016, Pates and Schmidt 2007). The narrative dominating the public discourse on trafficking victims over the last decades represents them as rather young women, innocent, helpless, and foreign, characteristics often not found in presumable victims in 'real life' (Snajdr 2013). The success of this narrative, although different research works have challenged it (e.g. Andrijasevic 2007, O'Connell-Davidson 2006), can be explained by the moral comfort it affords abolitionist Western societies that see sex work as a form of gendered violence. This dominant representation of the victims as pure and passive women, unwilling to 'sell their body', leads to certain expectations on the behaviour and appearance of the victims both by the police and in court proceedings. To live up to these expectations, victims would have to display fear and insecurity towards their exploiters, and gratitude and cooperation towards the police and courts (Pates, Dölemeyer and Leser 2016). Therefore, a number of cases which, according to the particular legal criteria, could be understood as human trafficking, are not identified as such in the everyday practices of state authorities because they do not fulfil the criteria of "ideal victims" (Jaksic 2016, see also Leser in this special issue). To make these 'problematic' subjects legible as victims and thus governable for state authorities, mediation and translation is necessary - not only in the sense of linguistic translation but also as "a theoretical metaphor through which to think about difference" (Giordano 2014: 15). 
Foreign sex workers are at the same time "emblematic figures of singularity" (Giordano 2014: 7) and "generalized others" (Massari 2009): they carry the stigma of being a victim and a prostitute and thus embody a doubled (cultural and sexual) otherness and an immeasurable difference, that makes them unique and exceptional. On the other hand, however, they epitomize the foreign, ethnic 'other' in general (Andrijasevic 2014, Giordano 2014: 7, Jacobsen and Stenvoll 2010).

In this context, German and French counselling centres have established themselves as mediators. They identify cultural differences as one central, explanatory factor for the non-recognition of victims. Bridging such (previously stated) cultural differences has become one of their core tasks, which in turn makes them indispensable for state law enforcement. To show how this works, we carried out over 30 problem-centred interviews with counselling workers in both countries, along with participatory observation of their daily work, the training sessions they held for other government or non-governmental organizations (in France) as well as round tables and specialized conferences on human trafficking. Additionally, we observed court proceedings and conducted interviews with attorneys, judges and state attorneys as well as police officers in both countries.

In our contribution, we concentrate on our interview partners' constructions of cultural difference (and its bridging) with respect to 'Roma' and 'Nigerians'2. Both German and French counselling centres address 'Roma' and 'Nigerians' as important target groups. Both define them in ethnic terms (as belonging to a certain ethnic group) and describe the exploitation as taking place within the respective ethnically defined networks and communities (i.e. both exploiters and exploited); cultural difference seems to be in both cases 'obvious'. This is consistent with general public discourses: In France as well as Germany, 'Nigerian prostitutes' (as an epitome for highly exploited Western African Women in prostitution) as well as 'Roma prostitutes' (meaning very marginalized women in prostitution from national minorities in Eastern Europe, especially in Romania and Bulgaria) have become a symbol of exploitation and otherness. Both represent in public and media discourse the ethnic and social 'other' of the respective majority society, and both are understood as experiencing particular forms of sexual and psychological violence.

An increasing number of academic research and media reports have described specific practices of Nigerian trafficking networks, focussing on juju $u^{3}$ and debt bondage (e.g. Baarda 2015, ECPAT France 2019, IFRA Nigeria 2019, Lavaud-Legendre 2013, Siegel and

Although we do not use quotation marks for every occurrence of national and/or cultural categorisations, we explain below that these categories should be used with caution because of the reification and homogenization of alleged cultural characteristics that usually goes along with them when used by the state and non-state actors studied here.

3 The term juju is used in the French interviews, whereas voodoo is used in the German context. Juju and voodoo refer to two different religious practices, but in the German context this differentiation seems to have become blurred and juju is equated with voodoo. 
De Blank 2010, Simoni 2013). Studies in anthropology, psychology or ethnopsychiatry have concerned themselves with the question of what special measures are required for the psychological care of Nigerian women in prostitution (see Beneduce and Taliani 2006, Giordano 2014, Taliani 2012), therefore contributing to their presentation as radically 'different'. In the case of Roma women, the othering operates above all by reducing their bodies to reproductive work and/or sexuality (by associating Roma women with early and frequent pregnancy on the one hand, prostitution on the other) as well as various psychic stigmas which would result from intra-family violence, lack of hygiene or nutrition (Prud'homme 2016, Vuattoux 2016). In media reports, examples of destitute, poverty-driven prostitution are related to 'Roma' (including people from other minorities, e.g. Turkish speaking minorities in Bulgaria) as epitome of poor, uneducated Eastern European women with vulgar behaviour, seen both as victims and cause of violence (e.g. Gerber 2012, Stoldt 2014).

Similarly, French and German counsellors consider both 'Nigerian' and 'Roma' women in prostitution as particularly marginalized and hard to 'read' in established legal or state categories, difficult to identify as victims of human trafficking. However, whereas counselling centre staff (as well as police) describe Roma as difficult to approach because they withdraw themselves from any assistance, they argue that Nigerians are identifiable as victims and accessible for counselling centres, but difficult to identify for the state as they do not match the dominant representations of a victim. Despite this alleged difference in their accessibility for assistance, and although 'culture' plays quite a different role in French and German public policies, our comparison of how these two groups are addressed shows many parallels in the way counselling centres assume the role of cultural mediation and thus help to turn these 'impossible victims' into governable subjects.

\section{Victim Support Organizations in France and Germany: Different Regulatory Framework, Similar Governing Practices?}

The legal frameworks and structures regulating human trafficking in Germany and France are characterized by a series of differences that also shape the work of counselling centres for trafficking victims. Whereas Germany has taken a regulationist approach to prostitution, which includes the regulation of voluntary sex work as a professional activity since it became legal in 2002, French law is still marked by abolitionism, meaning that every kind of prostitution is considered exploitation. Additionally, the two countries differ in the form of collaboration between non-governmental organizations and the state. In Germany, the collaboration of counselling centres with the police is contractually regulated at the level of federal states, defining the justifications, forms and limits of cooperation as well as the particular responsibilities and rights. Thus, counselling centres have officially assumed state duties of protection. In contrast, in France cooperation 
between non-governmental organizations and criminal justice authorities is based primarily on informal contacts. Yet criminal justice authorities in both countries rely on the collaboration with non-state actors to identify and support victims of human trafficking. In Germany, witness statements in court are indispensable to the judgment, and counselling centres play a central role in stabilizing the victim for the criminal proceedings. Although in France, criminal proceedings involving human trafficking do not rely on witness statements (Darley 2017), state prosecutors are explicitly requested by the Ministry of Justice to secure the presence of the victims as often as possible, as this is believed to encourage higher sentences for the accused by involving the judges emotionally.

Besides such legal and organizational aspects, the different impact and understanding of 'culture' in German and French public policies makes a comparative investigation of its role in trafficking victims' identification particularly relevant. The German model is shaped by a so-called 'multikulti' approach, which mainly understands differences between those perceived as foreigners and the so-called 'native' population as culturally anchored and therefore promotes the 'intercultural opening' (interkulturelle Öffnung) (Gauthier 2017, Schröer 2007) of the receiving society. The French so-called Republican model of integration, on the other hand, is based on the official negation of cultural differences (Mazouz 2017). Despite these differences, 'culture' functions in both countries as a container term (Hess 2015, Huntington 2002): it implicitly or explicitly conceives cultures as congruent with nations ('German culture' for instance), with larger geographic areas ('African' or 'Eastern European culture') or with subnational or transnational minorities, such as e.g. 'Roma'. In other words, in both countries, 'culture' is implicitly understood as based on descent and geographically and ethnically ascribes people to their 'origin' (Terrio 2009).

The work performed by counselling centres that makes them so valuable for the authorities firstly includes the provision of housing and caring for victims who are (potential) witnesses, since this is the only way to ensure that the witnesses will be available during trial. In both countries, moreover, the counselling centres are generally the first to identify the victims as such and to establish contact with the criminal justice authorities: women identified as (potential) trafficking victims often have first sought help at counselling centres or been identified by them during outreach work on the street (see below). Furthermore, counsellors help their clients to make use of the support available to them, register with the authorities, and more generally adapt to the authorities' expectations; and they advise various authorities how to better understand and to approach the trafficking victims. They thus become brokers (Bierschenk, Chauveau and Olivier de Sardan 2001) between authorities and victims, and have a certain power to interpret as to who is to be understood as a victim and how.

However, this occurs in very heterogeneous ways and shows significant differences between the two countries, but also within each country and between the various 
organizations. In Germany, the counselling centres often have a background in women's rights and immigrants' support, whereas in France they come from either health-based preventive work or abolitionist lobbying. Their references to cultural explanatory patterns reflect these diverse traditions. In Germany, professional counsellors in interviews generally preferred class-based or gender-based ascriptions to ethnicised cultural explanations. Nonetheless, ethnicising elements are also prominent: counselling centres for instance specialize in target groups of a particular 'origin', which is generally justified by the linguistic competence of the employees. This also furthers ethnicised narratives on how women are exploited within prostitution, which counselors hold to differ according to their belonging to one or the other 'ethnic group'.

In the interviews conducted in France, in contrast, police and judicial actors as well as counsellors immediately refer to the alleged 'cultural' dimension of the different forms of human trafficking and primarily distinguish between the Roma, the Nigerian and the Chinese potential victims (and perpetrators). Accordingly, the women offered care are divided between the counselling centres primarily along their (assumed) national origin. Although this distribution can also be explained by linguistic competences, it has concrete implications for the classification as victim, as the organizations differ through their very differentiated relations to the issue of human trafficking. Abolitionist organisations that arose as Christian initiatives have long rejected human trafficking as a category of action, since they see it as an illegitimate distinction between coerced and voluntary prostitution. Such abolitionist groups have a large influence on both the political debate and the legal regulations (Mathieu 2014), as they are more engaged in lobbying than in actual counselling work. However, criminal justice actors often credit counselling centres stemming from health-based preventative work (and with a non-abolitionist approach to prostitution) with more specialized knowledge from the field. Several of these organizations take a so-called 'communitarian approach' (approche communautaire), meaning that women who are or have been involved in sex work should engage in support activities for other women. Due to the high proportion of Nigerian women in street prostitution in most French cities, this communitarian approach has led primarily to the recruitment of former Nigerian sex workers as cultural mediators in counselling centres. Therefore, the specialized knowledge these organizations are credited with by the criminal justice authorities relies among other things on their alleged 'cultural expertise' on Nigerian women, based on which a number of training sessions are conducted by the counselling centres for criminal justice authorities.

\section{Mediation Work: Making the Victim Exist for the Authorities and Awakening an Awareness of Victimhood}

As we have already explained, we concentrate here on two ethnically defined victim groups which are not only prominent in the accounts of our interview partners, but also 
seem to represent the culturally different 'other' and are therefore considered to be especially problematic target groups: 'Nigerian' and 'Roma' potential victims of trafficking. Despite the contrasts between German and French approaches to human trafficking into sexual exploitation, to so-called 'cultural differences' as well as regarding the support structures for presumable trafficking victims, some of the narratives about these two 'target groups' show remarkable similarities.

Training sessions on identifying victims held by social workers and psychologists working in counselling offices in France usually start with the presentation of a so-called 'typical story'" of a victim of trafficking. Although the titles of the training courses we observed did not highlight the trafficking victims' origins, the exposed typical narratives, like the fictional story quoted below (and which counsellors describe as based on different "real stories"), made it clear from the beginning that the training would focus on Nigerian women in prostitution:

My name is Joy [...] I have a younger brother, Peter, who's 13 years old. I was born on 11.06.1994 in Nigeria, Bénin-City, Edo state. I belong to the Bini ethnicity. My father was a street wheat seller. We went to Salvation majestic church. In 2010, I left school at the age of 16, when my father died. After his death, life was difficult. I started to work in a shop. One day a customer offered to help me. Two days later I had an appointment with her to get a passport from the Immigration Office to go to France. Then she took me to an Ayelala 4 temple, where a man scarified my body and took some hair and nails from me, as well as my underwear, before placing them in front of an Ayelala statue. Then I had to swear that I will never tell anything to the police once in France.

(Counselling centre, Training on Victim Identification, November 17, 2015, France $)^{5}$

This highly standardized and ethnicised narrative, presented by the trainers as a fictive compilation of real cases they have to handle, not only tells a prototypical story of the recruitment, but goes further with the journey and fate in Europe. Similar stories appear in numerous German and French media reports (for example Harel 2018), as well as in the accounts counsellors gave us in interviews. The reference to a juju ritual, in which the women are obligated to silence, is never missing and presented as enabling a unique psychological subjugation of the victims.

\footnotetext{
4

Ayelala is a popular deity in the western part of Nigeria, known for punishing crime of various types. Juju rituals take place in Ayelala temples (IFRA Nigeria 2019).

All names are pseudonyms, in this quote as well as in further quotes. All interviews were originally conducted in French (in France) and German (in Germany) by members of the respective research teams (as long as not specified: Mathilde Darley in France, Anne Dölemeyer in Germany) and quotes have been translated by the authors. For reasons of anonymity, the exact city/location of the interviews is not specified.
} 
Nigerian women are really the community for which the concept of human trafficking makes the most sense: Nigerian women trafficking, that's a caricature taken to the extreme! You take the definition of human trafficking, and that is precisely what they [the Nigerian women] are experiencing! This was a relatively unknown phenomenon for a long time, since the women speak very little, because they are always under enormous influence, it is an incredible amount of work to uncover this!

(Interview with Sandra, counsellor, September 17, 2015, France)

As shown in this quotation as in many media reports, Nigerian women are now generally understood as the prototype of the innocent trafficking victim - a role previously ascribed to Eastern European women in the 1990s (Andrijasevic 2007). Part of this narrative is that these women "speak very little", as the counsellor says, which makes them both extremely vulnerable and hard to identify as trafficking victims. In this account, it is the particular work of the counsellors as mediators that enables them to be seen and heard, and therefore to become recognizable as victims.

Whereas Nigerians seem to embody the epitome of the absolute victim, the staff of French and German counselling centres we interviewed identified 'Roma' as another ethnicity affected by exploitation in terms of prostitution but hardly reachable due to the structures of their exploitation as well as their socialization. The term Roma refers to an ethnically connoted collectivisation of women and men from Eastern Europe ascribed to a (linguistic) minority (even if they do not necessarily speak Romani), and especially French interview partners also used it an equivalent of 'Romanians' (and, vice versa, 'Romanians' as equivalent of 'Roma'). The features that group the women concerned together are poverty, illiteracy, gender-related intra-family violence, as well as state and societal discrimination in their country of origin. Thus, police as well as counselling centres often do not perceive them as classic trafficking victims, but rather as victims of structural disadvantages, unable to understand their own interests.

They don't necessarily migrate for the same reasons: the Nigerians came to have a better future, whereas for young Romanians the concern is more precariousness, intra-familial or marital violence. These are profiles that will not attempt too much to get out of their situation. Often these women are hardly autonomous, they have to be accompanied everywhere, even on public transport, and they can't read... (Interview with Melanie, counsellor, October 12, 2015, France)

The women whom the counsellors we interviewed identify as Roma appear so problematic and so difficult to approach that even these specialized counsellors can hardly understand their needs and thus mediate for them:

We're still working on this, somehow we don't have the right offer [...] for the women. For example, [...] many other women are happy about the offer of German 
language courses, because of a job, jobs are possible and such things, [...] many of the [Roma] women, they don't see any point in it, what the point [of learning German] is, they have very different needs.

(Interview with Kristin, counsellor, July 16, 2015, Germany)

In the accounts of the counsellors (as well as police officers) we interviewed, Roma are, just like Nigerians, the epitome of a problematic victim group, but in a different way: according to these accounts, the sex workers classified as Roma are clearly victims of difficult circumstances, but not unambiguously identifiable as victims of human trafficking. In addition, they withdraw not just from the justice system but also from the counsellors. As one counsellor puts it: "We never again got access to that [Roma] woman. They have, Roma have a clan relationship [...] when you have [to deal with] a clan, you can just give up" (Interview with Ines, counsellor, December 16, 2014, Germany). Roma women are elusive even for these specialized caretakers.

According to our interview partners, however, both groups have in common that they are not aware of being victims of crime. This underscores the importance they see in care work, since only they, as social workers, are in a position to unveil or uncover the awareness of victimhood in their clients and bring them to see themselves as victims. They describe Nigerian women as generally unwilling or unable to testify as victims of human trafficking. This is partly linked to an ethnicised othering that attributes to Nigerians an emotional and perceptual world entirely alien to Western Europeans:

[Irène] - As to the question: what is seen as violence, for young women from Nigeria, I don't know what it means for them. I think it is somehow, so to speak, a very European concept, mental suffering, mental, somatic violence... Being mistreated is not necessarily something they know, something they speak about. Whereas for us...

[Christiane] - They speak differently, think differently in Africa.

(Interview with Irène and Christiane, counsellors, July 2, 2015, France ${ }^{6}$ )

Otherness could not be formulated any clearer: Nigerians, according to the statement here, do not recognize violence, because they think and act entirely differently than Europeans, and this explains the difficulty these women have seeing themselves as victims. This culturalist absolute thus creates a great need for experts who can help to bridge this cultural divide and awaken a consciousness of victimhood:

[Nigerian women] don't even know what they are suffering from, they feel oppressed and don't even know where it comes from! [...] So we are working on their victim status, we see them as victims and get them to recognise themselves as victims.

\footnotetext{
${ }^{6}$ Interview conducted by Lilian Mathieu.
} 
(Interview with Caroline, psychologist at a counselling centre, October 27, 2015, France)

Counsellors in France and Germany frame the lacking consciousness of victimhood as the effect of an identified cultural difference and present it as the central difficulty they face. Many interview partners describe how their clients originally came to them with other concerns, before slowly approaching the topic of exploitation and human trafficking. Then, the counsellors describe how they incidentally explain the legal situation and the support possibilities. As they put it, the clients would then somehow have enough trust and sufficient understanding of their situation to say that they were victims of exploitation.

Once counsellors have thus convinced their clients to understand themselves as victims of a crime legally defined as human trafficking, they must then ensure that public authorities equally come to understand these women as trafficking victims. This requires them to become recognizable not just by the 'facts' but also through their behaviour and the way they speak and act. Accordingly, part of the counselling work consists of conveying the behavioural rules expected by the authorities to the victims of human trafficking. This relies on the assumption that trafficking victims are culturally and socially deviant from the (French or German) norms, and that this deviation causes severe problems, e.g. regarding the assessment of a victim's credibility. The following quote refers to a member of a Turkish-speaking minority in Bulgaria, a group that is often lumped together with 'Roma' and said to share similar characteristics and needs?:

A few years ago, I had a trial where the witness was a member of a Turkish minority. And she couldn't read, couldn't write. And times as well - she wrote for example in the statements, it was dark, it was night. That was at 4 PM in November. But for her it was dark and night! And there were many inconsistencies, which the judge or the attorney didn't understand too well, why is she saying such nonsense. But that was her perception. And with her upbringing she couldn't describe it at all. For her, a week was already an eternity.

(Interview with Olivia, counsellor, April 14, 2015, Germany)

Here the client's perception and understanding of time is simply presented as different from what is taken for granted as quasi-natural in the courtroom and by the counsellor: the originally more socio-economic explanation of the woman's otherness becomes an ethnicized cultural otherness. However, the witness here is not the only problematic party, the court is as well. The descriptions of the highly professional German counsellors almost always deal with the incompatibility between the client's world of perception on

\footnotetext{
$7 \quad$ The matter of Turkish Bulgarians and Roma is indeed complicated. According to Vassilev, there is no clear indicator whether someone is a Rom, and ,(1)argely due to the stigma attached to being a Roma, the Roma often tend to identify themselves either as Turks or as Bulgarians“ (Vassilev 2003: 42).
} 
the one hand and the logics and expectations of the law enforcement authorities on the other. In principle, the difficulties related to court requirements on testimonies apply to almost all trafficking victims, regardless of their nationality. Yet counsellors and judges indicate in our interviews that they see foreign women and especially members of Eastern European minorities (Roma, Turkish minorities in Bulgaria) and Nigerians as struggling far harder than most German witnesses, because of language, translation and so-called 'cultural' barriers.

This of course does not mean that German (or French) victim-witnesses will not meet difficulties if their testimony does not fit the expectations of police or judges; however, the perceived 'cultural' otherness of foreign victims increases the expectations put on them for demonstrating their credibility and eligibility as victims. In a context where language cannot - because of the language barrier and the loss of meaning resulting from translation - function as a site where credibility is constructed, the behavioural and emotional expectations potential foreign victims face when displaying suffering increase to make up for this 'cultural' gap.

A lawyer working for a French counselling centre and specialized in legal assistance for Nigerian victims of trafficking relies on the alleged 'cultural' difference between Africa and Western Europe to prepare women for their asylum interview:

You are supposed to give a lot of details. The more details you give, the more convincing you are. The judges are going to examine your case with their own mind, French people's mind, white people's mind! (Interview with Géraldine, Legal counsellor, June 12, 2016, France)

Here the othering is primarily justified by the idea of a fundamental gap between black and white culture, making it necessary for the counsellors to help their clients adapt to the authorities' expectations. To do so, the counsellors focus not so much on legal or procedural aspects that make a testimony in court a difficult experience for any litigant, but rather on the necessity to make their clients 'culturally conform' to the stereotypes they attribute to state authorities.

The Nigerians are impolite. They yell "chocolate, chocolate" and don't even say "please". I explain to them that they have to learn how to say "s'il vous plait" and "merci", since this is how it works in France. It is a cultural characteristic in Nigeria; these forms of politeness are not used [...]. They are not polite, but we have to teach them this, for in France you need this in order to receive something from the authorities.

(Frédéric, counsellor, Observation during outreach work, April 27, 2016, France $^{8}$ )

\footnotetext{
${ }^{8}$ Observation conducted by Muriel Mille.
} 
The culturalism at stake here, i.e. essentializing identities and assigning specific characteristics to specific ethno-racial groups, can be seen as a racialization process aiming not only at giving a 'cultural' explanation for behaviours labelled as deviant but also at justifying the role of counsellors/social workers as 'brokers' in preparing the victim for an emotional and cultural performance that goes beyond merely narrating their experiences of (sexual) violence. As several studies have shown (Leser, Dölemeyer and Pates 2017), the 'appropriate' emotional behaviour expected from victims and which has here (according to the counsellors) to be taught to them, especially if they are of 'foreign origin', includes politeness, respect, acknowledgment, gratefulness (Darley 2014, Graham 2002) but also despair and helplessness.

So, when the woman was clearly a victim, when she cried a lot and was completely helpless, then the police went to great lengths for her. But if she flipped out now and again and said son of a bitch once, then the mood was very different, and actually that's not how it should be.

(Interview with Britta, former counsellor, December 3, 2014, Germany)

This is confirmed by representatives of the French law enforcement, who also place emotional expectations on victims so that they can perform their duties (Graham 2002: 211):

If victims are present in the criminal proceedings, it changes everything. I love having the victims there, they get everyone crying.

(Interview with a public prosecutor, December 9, 2014, France)

For foreign victims of sexual exploitation, expressive forms of mental (and/or physical) suffering thus seem to become particularly important, especially when they fail to meet other requirements such as coherent narratives suited to the needs of court records. German (or French) victim-witnesses might also show inconsistencies in their testimonies and accordingly might meet difficulties if their emotional performance does not fit the expectations of police or judges; however, for foreign women, the perceived 'cultural' otherness makes the display of suffering even more important in order to make up for this gap and be acknowledged as 'victims'. With respect to Nigerians, counsellors also understand their role as having to mediate between two systems of belief. Again and again, in the interviews with counselling offices, it is emphasized how 'we' find it difficult to understand the belief in juju (voodoo), since this involves a completely different belief system. The following statement by a counsellor in Germany shows clearly the efforts to translate their clients' stories into an explanatory, understandable pattern for Western Europeans:

Of course, a lot is manipulated. I had a young woman who said nothing for a long time and then sat in prison herself, a Nigerian woman. [...] Then she received counselling there, then she made a statement and three weeks later her father was 
in a traffic accident. The woman felt unbelievably responsible for it, she said it was voodoo. [...] She never got past this. It made her crazy. And I mean, whoever's been in Nigeria knows that everyday people end up in traffic accidents, since the traffic there is horrifying [...]. But for her it was completely clear that it was the voodoo oath. And that was then what was crucial.

(Interview with Nadine, counsellor, January 12, 2015, Germany)

Here the counsellor builds a bridge by justifying her client's behaviour with an explanation that could also be accepted by a Western police officer: even if ultimately the client appears superstitious, from the point of view of the officer or judge, her superstition explains her behaviour convincingly. Since juju is described as the central axis of both the mechanism of debt towards the traffickers and the lower willingness of victims to testify, and more broadly as one of the leading principles of 'the' Nigerian culture, counselling centres establish themselves as indispensable experts in the mediation between victims and authorities.

\section{Knowledge Transfer Between Counselling Offices and Authorities}

Both in Germany and France, the counselling centres position themselves as mediators who can use their specialized knowledge to bridge the differences between purported victims of human trafficking and authorities. But the focus on cultural translation tends (often contrary to their own stated intention) to divide victims into ethnic groups conceived as culturally, socially and even emotionally homogenous. These groups are subject to expectations aimed at adapting them to the particular national (French or German) 'culture', which is also implicitly understood as a homogenous and stable construction. The assumption is that this adaptation will make them legible for local authorities and, simultaneously, governable - i.e. local state techniques to read and to steer behaviour can successfully be applied. In both France and Germany, however, the assumption that illegibility and non-compliance are based on cultural differences linked to the women's foreign 'culture' may also contribute to reifying these alleged cultural differences. In contrast to this similarity between the two countries, the counsellors' relations to various criminal justice authorities differ. Here, the issue of cultural compatibility between the parties seems to be understood differently in the German and French contexts.

\subsection{Germany: Mediation Work as a Reciprocal Adaption Between Victims and Authorities}

The interview partners in German counselling centres often depict the incompatibility between victims and authorities as the result of divergent conventions and expectations on both sides. To some extent, the counsellors also present the victims' unsuitability as 
the result of the inability of criminal justice authorities to cope with their alterity and to correctly interpret their behaviour or their statements - for example, when police officers interpret a victim's impolite behaviour as a sign that they are not a victim at all. Thus, police and courts, with their partly unfulfillable requirements, seem to be at least as much a part of the problem as the victim testifying, which makes training for criminal justice actors particularly necessary.

I believe the difference is that we now have an awareness of this. This was also a large part of the sensitization during police training, that is, what does trauma do to people, and that aggressions can also go along with trauma and such things, but most police officers - well I think the difference is, that they might be aware of it, but not necessarily act accordingly in the situation.

(Interview with Britta, former counsellor, December 03, 2014, Germany)

There are signs that the strong professionalization of the German counselling centres and the contractually regulated cooperation with authorities have led them to position themselves as legitimate partners and thus to have certain expectations on the behaviour of criminal justice authorities or to influence how these authorities interact with victims. This is underlined by a basic understanding of cultural difference as a relative concept that has two sides, both of which follow their own logic.

This means that the people working [in specialized, trained units] have some clue about this area, can respond with the appropriate sensitivity, that by now you don't have, you know, naked breasts hanging on the wall [in the police office] and so on. Yeah, there were times when there were things like that. (Interview with Ines, counsellor, December 16, 2014, Germany)

Thus, the client (the trafficking victim) is not the only one who in the counsellors' perception needs to adapt: the behaviour of authorities and their ways of understanding the world are not taken for granted, either, but are rather seen as in need of explanation and change as well. The counsellor's quote shows that to her understanding cultural difference as well as adaptation is a two-way street. This hints at a perception of 'culture' not only in view of the 'African others', but also as specific institutional culture(s) - an aspect we cannot elaborate here but that is worth keeping in mind.

\subsection{France: Cultural Expertise as the Bridging of Working Differences Between State and Non-State Actors?}

In the training that French counselling centres provide for criminal justice actors, it is also frequently emphasized that they need to be trained in the cultural particularities of the so-called 'Roma' or - even more - 'Nigerian' human trafficking, i.e. involving respectively Roma or Nigerian victims and/or perpetrators. In the case of so-called Nigerian networks, the focus is in particular on the power that juju has over people, an understanding of which would make it possible for criminal justice authorities to take the narratives of the 
witness seriously (and thus to pursue the perpetrators). A trainer who is considered an expert in Nigerian human trafficking because of his double legitimacy on this issue as a counsellor and as a researcher, explained in a training session for judges and state prosecutors that he would provide them with "anthropological knowledge":

The investigators and judges have to understand the function of the networks very well in order to carry out the questioning, so that the victims can testify: as long as the victims have the feeling that their contact partner does not understand what they're saying, they won't talk. Whereas they'll talk, if their contact partner has mastered the cultural aspects. When the contact partner understands the meaning of juju, he has a better chance that the victim will reveal information.

(Elisabeth, Counsellor, training for judges, November 22, 2015, France)

As we see here, the ability claimed by counsellors to better understand and interpret the world of their clients is also interpreted as a potential contribution to easing the work of police investigation. The interviewed police themselves explain that they choose the counselling centres with which they work informally according to whether they are capable of "distinguishing between true and false victims" (Interview, police officer, France, November 2016). Counsellors therefore foreground their particular competence in uncovering "liars" thanks to their cultural expertise:

It is always interesting to see how women react when we propose a conversation with a mediator. If they refuse, that might be a sign that they have something to hide and fear that the Nigerian mediator will quickly catch on.

(Interview with Caroline, psychologist, counselling centre, October 27, 2015)

This segregation of 'false victims' (i.e. having "something to hide") as kind of cultural competence gives the counselling centres legitimacy as contact partners for the police, particularly if they buy into the police's suspicion of some victims actually being 'false'. One of the principle differences to German counselling centres is the thoroughly competitive context of non-state assistance for sex workers in France. This leads to struggles for both state funding and recognition by state authorities and puts counselling centres in France in a weaker structural position than their counterparts in Germany. This fragile position could explain why and how their cultural expertise in interacting with state authorities goes hand in hand with having to accept some of the authorities' working logics, such as the uncovering of 'false victims' as a central part of their activity. In addition to this, the nature of the crime also plays a role: the consensus around the "moral panic" (Mathieu 2015: 32) that goes along with human trafficking for the purpose of sexual exploitation seems to make this slight blurring of the division of labour between non-state actors and criminal justice authorities acceptable here, while it would be unthinkable in a different area. 


\section{Conclusion}

There is a series of significant differences between the German counselling centres that are institutionally integrated into state practices of identifying and caring for victims of human trafficking and the counselling centres in France that cooperate more informally with state authorities. These differences can be found e.g. in the structural position, in the legal and political framing conditions with regards to the criminal prosecution of human trafficking in prostitution, in the funding and degree of professionalisation of the work. Nonetheless, in their narrations of their work, both the French and German counsellors describe various incompatibilities between state institutional logics and actions, and their clients' logics and behaviour in a similar way. In their own explanations, they partly codify these differences and their causes in ethnic and cultural terms, partly also as based in socio-economic patterns. Essentializing culturalist explanations - understood within a container model of national, homogeneous cultures (Çağlar 1990) - are used above all when it comes to raising the awareness of the public or the authorities, who are to be brought to acknowledge even those persons who fall outside the narrow norms of the standard narrative as victims of human trafficking. Thus, in both countries, 'culture' is central when it comes to producing governable subjects.

However, the particular national and institutional contexts in France and Germany go along with a different weighting of the cultural explanatory pattern and its function in the forms of collaboration between criminal justice authorities and counselling centres. Whereas in Germany the so-called 'multikulti' approach in public policy and the professionalization of the counselling centres coincide with (and might encourage) reflections not just on the alterity of the culture of the 'other' but also on one's own alterity, the French universal-republican model makes primarily visible the differences of the 'others'. The more fragile position of the counselling centres in France, who have to struggle for (financial) recognition and legitimation from the authorities, seems to contribute to their foregrounding of their cultural expertise. This furthers othering of their clients, legitimated by criminal justice authorities when it corresponds to the logic of their investigative work and makes it possible to distinguish between so-called 'true' and 'false' victims. In contrast, the stable role of counselling centres in Germany as official partners of the criminal justice authorities could explain that while they choose cultural explanatory models, they understand cultural differences as a sign of necessary mutual adaptation between two cultures and their so-called cultural expertise as an instrument to encourage criminal justice authorities to adjust their working practices.

But in both countries, counselling centres position themselves with their cultural expertise as indispensable mediators, albeit in different ways. Hence our comparison here provides a contribution to a broader comparative analysis of the role of culture in the German and French context. It also invites further research taking into consideration not just public policies, but also the concrete everyday work practices around the process of their implementation, with a particular emphasis on the role of non-state actors. 


\section{References:}

Andrijasevic, R. 2007. Problematising Trafficking for the Sex Sector: A case of eastern European women in the EU. In T. Spijkerboer \& S. Van Walsum (eds.),Women and Immigration Law: New Variations on Classical Feminist Themes (pp. 86103). Abington: Routledge.

Andrijasevic, R. 2014. The Figure of the Trafficked Victim: Gender, Rights and Representation. In Evans, M. et al. (eds.).The SAGE Handbook of Feminist Theory (pp. 359-372). London: SAGE Publications Ltd.

Baarda, C.S. 2015. Human Trafficking for Sexual Exploitation from Nigeria into Western Europe: The Role of Voodoo Rituals in the Functioning of a Criminal Network. European Journal of Criminology, 13(2), pp. 1-17.

Beneduce, R. \& Taliani, S. 2006. Embodied Powers, Deconstructed Bodies Spirit Possession, Sickness, and the Search for Wealth of Nigerian Immigrant Women. Anthropos: International Review of Anthropology and Linguistics, 101(2), pp. 420-449.

Bierschenk, T., Chauveau, J.-P. \& Olivier de Sardan, J.-P. 2001. Politische Makler und Entwicklungsmakler in der Sozialanthropologie: Ein Literaturüberblick. Berlin: Das Arabische Buch.

BKA (Bundeskriminalamt) 2017. Bundeslagebild Menschenhandel 2016. Available at: <https://www.bka.de/SharedDocs/Downloads/DE/Publikationen/Jahresbericht eUndLagebilder/Menschenhandel/menschenhandelBundeslagebild2016.html> (Accessed 15 April 2019).

Çağlar, A. S. 1990. The Prison House of Culture in the Studies of Turks in Germany. Berlin: Das Arabische Buch.

Darley, M. 2006. Le statut de la victime dans la lutte contre la traite des femmes. Critique internationale, 30, pp. 103-122.

Darley, M. 2014. Les coulisses de la nation : Assignations genrées et racialisées dans les pratiques d'assistance aux étrangers en situation irrégulière. Sociétés contemporaines, 94, pp. 19-39.

Darley, M. 2017. L'exploitation sexuelle en procès : perspectives comparées francoallemandes. Cahiers de la Justice, 1, pp. 105-115.

ECPAT France. 2019. Religious, Social and Criminal Groups in Trafficking of Nigerian Girls and Women. Final report of the Pac king Project. Available at: $<$ https//ecpat-france.fr/www.ecpat-france/wpcontent/uploads/2019/04/WEB_rapport-nigeria_ENG.pdf $>$ (Accessed 23 November 2019). 
Gauthier, J. 2017. Le policier et le culturel. Police et minorités à Berlin. Cultures \& Conflits, 107, pp. 123-141.

Gerber, S. 2012. "Weg der Wanderhuren" zeigt Roma-Leid in Nordstadt und Bulgarien. Westfälische Rundschau. Available at: <https://www.wr.de/staedte/dortmund/weg-der-wanderhuren-zeigt-romaleid-in-nordstadt-und-bulgarien-id6218982.html> (Accessed 22November 2019).

Giordano, C. 2014. Migrants in Translation. Caring and the Logics of Difference in Contemporary Italy. Oakland: University of California Press.

Graham, M. 2002. Emotional Bureaucracies: Emotions, Civil Servants, and Immigrants in the Swedish Welfare State. Ethos, 30(3), pp. 199-226.

Harel, M. 2018. Prostituées nigérianes victimes du „juju“. Le Monde Diplomatique.. Available at: <https:/www.monde-diplomatique.fr/2018/11/HAREL/59215> (Accessed 23 November 2019).

Hess, S. 2015. Jenseits des Kulturalismus. Ein Plädoyer für postkulturalistische Ansätze in der kulturanthropologischen Sozialforschung. In Glückmann, M. \& F. Sparacio (eds.), Spektrum Migration (pp. 37-64). Tübingen: TVV-Verlag.

Huntington, S. 2002. The Clash of Civilizations and the Remaking of World Order. New York: Simon \& Schuster.

IFRA Nigeria. 2019. Oath Taking in Edo: Usages and Misappropriations of the Native Justice System, Working Paper Series, 55. Available at: < https://www.ifranigeria.org/files/54/IFRA-E-papers/147/Oath-taking-in-Edo-Usages-andMisappropriations-of-the-Native-Justice-System.pdf $>$ (Accessed 28 December 2019).

Jacobsen, C. M. \& Stenvoll, D. 2010. Muslim Women and Foreign Prostitutes: Victim Discourse, Subjectivity, and Governance. Social Politics 17 (3), pp. 270-294.

Jaksic, M. 2016. La traite des êtres humains en France. De la victime idéale à la victime coupable. Paris: CNRS Editions.

Lavaud-Legendre, B. (ed.). 2013. Prostitution nigériane. Entre rêves de migration et réalités de la traite. Paris: Karthala.

Leser, J., Pates, R. \& Dölemeyer, A. 2017. The Emotional Leviathan - How Street-Level Bureaucrats govern Human Trafficking Victims. Digithum, 19. Available at: < https://digithum.uoc.edu/articles/abstract/10.7238/d.v0i19.3088/> (Accessed 15. April 2019).

Massari, M. 2009. The Other and her Body: Migrant Prostitution, Gender Relations and Ethnicity. Cahiers de I'Urmis, 12. Available at:

<https://journals.openedition.org/urmis/787> (Accessed 19 December 2019). 
Mathieu, L. 2012. De l'objectivation à l'émotion. La mobilisation des chiffres dans le mouvement abolitionniste contemporain. Mots. Les langages du politique, 100, pp. 173-185.

Mathieu, L. 2014. La fin du tapin. Sociologie de la croisade pour l'abolition de la prostitution. Lormont: éd. François Bourin.

Mathieu, L. 2015. Sociologie de la prostitution. Paris: La Découverte.

Mazouz, S. 2017. La République et ses autres. Lyon: ENS Éditions.

O'Connell-Davidson, J. 2006. Will the Real Sex Slave Please Stand Up? Feminist Review, 83(1), pp. 4-22.

Pates, R., Dölemeyer, A. \& Leser, J. 2016. Schwierige Verhältnisse: Menschenhandelsopfer und Geschlecht in Gerichtsverfahren. FEMINA POLITICA Zeitschrift für feministische Politikwissenschaft, 25(1), pp. 24-38.

Pates, R. \& Schmidt, D. 2007. Die Verwaltung der Prostitution. Eine vergleichende Studie am Beispiel deutscher, polnischer und tschechischer Kommunen. Bielefeld: Transcript Verlag.

Prud'homme, D. 2016. Du „soin global“ au traitement discriminatoire. La prise en charge de personnes identifiées comme roms dans un service de gynéco-obstétrique parisien. Terrains \& travaux, 29, pp. 85-104.

Ragaru, N. 2007. Du bon usage de la traite des êtres humains. Controverses autour d'unproblème social et d'une qualification juridique. Genèses, 1 (66), pp. 69-89.

Schröer, H. 2007. Interkulturelle Öffnung und Diversity Management. Konzepte und Handlungsstrategien zur Arbeitsmarktintegration von Migrantinnen und Migranten. München: Zentralstelle für die Weiterbildung im Handwerk e.V. (ZWH).

Siegel, D. \& De Blank, S. 2010. Women Who Traffic Women: The Role of Women in Human Trafficking Networks - Dutch Cases. Global Crime, 11(4), pp. 436-447.

Simoni, V. 2013. "I Swear an Oath”. Serments d'allégeances, coercitions et strategies migratoires chez les femmes nigérianes de Benin City. In Lavaud-Legendre, B (ed.), Prostitution nigériane. Entre rêves de migration et réalités de la traite (pp. 33-60). Paris: Karthala.

Snajdr, E. 2013. Beneath the Master Narrative: Human Trafficking, Myths of Sexual Slavery and Ethnographic Realities. Dialectical Anthropology, 37(2), pp. 229-256.

Stoldt, T.-R. 2014. Wenn das laute Stöhnen die Anwohner stört. Welt.de. Available at: $<\underline{\text { https://www.welt.de/regionales/nrw/article131710790/Wenn-das-laute- }}$ Stoehnen-die-Anwohner-stoert.html> (Accessed 22 November 2019). 
Terrio, S. J. 2009. Judging Mohammed. Juvenile Delinquency, Immigration, and Exclusion at the Paris Palace of Justice. Stanford: Stanford University Press.

UNO 2000. Protocol to Prevent, Suppress and Punish Trafficking in Persons Especially Women and Children, Supplementing the United Nations Convention Against Transnational Organized Crime, Adopted and opened for signature, ratification and accession by General Assembly resolution 55/25 of 15 November 2000. Available at:

$<$ https://www.ohchr.org/EN/ProfessionalInterest/Pages/ProtocolTraffickingIn Persons.aspx $>$ (Accessed 28 November 2019).

Vassilev, R. 2003. The Roma of Bulgaria: A Pariah Minority. Ethnopolitics, 3(2), pp. 4051.

Vuattoux, A. 2016. Le traitement institutionnel d'une minorité par la justice en Ile-deFrance : le cas des "jeunes filles roumaines". Canadian Journal of Women and the Law, 28 (3), pp. 646-667.

UNODC. 2018. Global Report on Trafficking in Persons 2018. Available at:

$<$ https://www.unodc.org/unodc/en/human-trafficking/publications.html $\geq$ (Accessed 15 April 201 
